PAPER • OPEN ACCESS

Soil characterisation for precision agriculture using remotely sensed imagery in southeastern Nigeria

To cite this article: O. T. Kayode et al 2019 J. Phys.: Conf. Ser. 1299012070

View the article online for updates and enhancements.

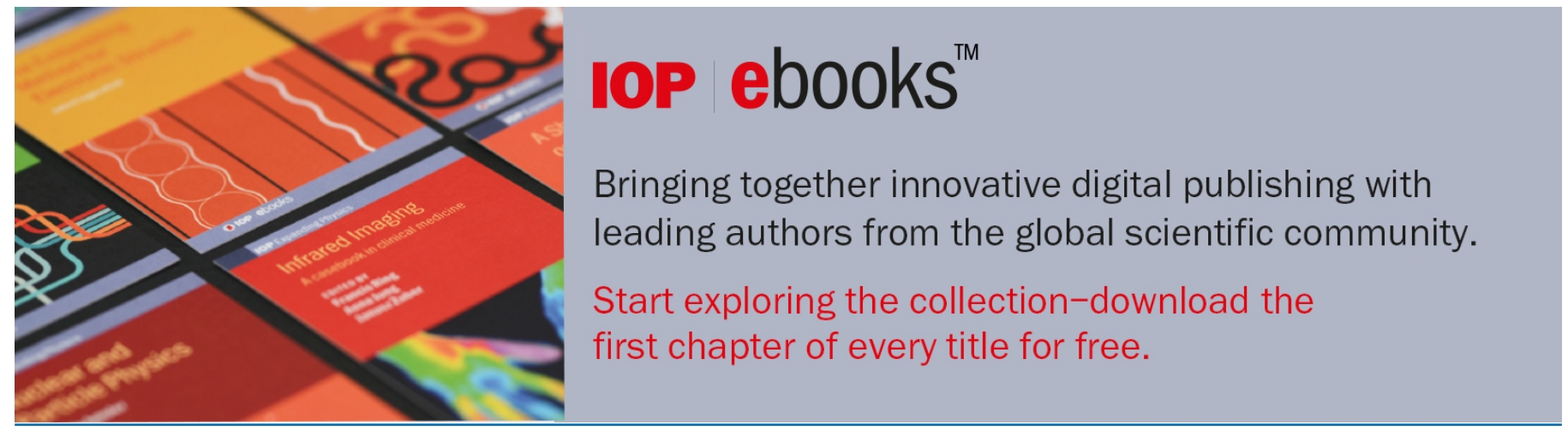

This content was downloaded from IP address 165.73 .192 .252 on 18/11/2020 at 09:57 


\title{
Soil characterisation for precision agriculture using remotely sensed imagery in southeastern Nigeria
}

\author{
O. T. Kayode ${ }^{1}$, A. P. Aizebeokhai ${ }^{1}$, A. M. Odukoya ${ }^{2}$ \\ ${ }^{1}$ Department of Physics, College of Science and Technology, Covenant University, Ota \\ ${ }^{2}$ Department of Geosciences, College of Science, University of Lagos Nigeria
}

Corresponding email: olusola.kayode@covenantuniversity.edu.ng

\begin{abstract}
Remote sensing techniques have been widely used for spatial assessment of soil properties. Traditional techniques involving soil sampling and laboratory analysis are expensive and labour intensive for large areas.High resolution remote sensing data and geographic information systems (GIS) were used for spatial characterization of soil properties in southeast Nigeria. Thesoil parameters investigated include soil texture, $\mathrm{pH}$ and drainage pattern. Thetexture, which indicates the sand, silt and clay content in the soil, showed that sandyclay and loamy sand are predominant for the areas investigated. The soils $\mathrm{pH}$ ranged from slightly acidic to strongly alkaline. The study has been specifically conducted to making adequate soil data available and acts as a reference for improving soil quality within the area.
\end{abstract}

\section{Introduction}

Soil, a natural and non-renewable resource found on the surface of the earth, supports human existence and plant growth. A good knowledge of its complex and dynamic nature helps to nurture healthy plants and improve crop yield. The heterogeneous nature of soil affects crop productivity [1]this sometimes makes agricultural inputs such as fertilizer, pesticides as well as irrigation activities inadequate for precision agriculture [2]. Suitable soils for both agricultural and engineering constructions are getting depleted [3 - 5]. Remote sensing and geographic information system (GIS) are advanced tools used to analyse spatial-temporal variability of soil properties. This technology from airborne and satellite platforms enable quick assessment of vegetation and soil properties and their response to global change over large areas [6-10]. Soil surface characteristics are mostly influenced and controlled by key environmental issues such as excess runoff, soil erosion, floods, contaminations and unbalanced water cycle, among others. For sustainable agriculture implementation an improved understanding of the soil is required [11].

In southeast Nigeria, particularly Abia, Anambra, Ebonyi and Imo states, soil erosion is one of the predominant ecological challenges they face as in most parts of the humid tropical 
zone $[12,13]$. The soils are structurally unstable and therefore prone to gully erosion $[14-16]$. Basically, traditional practices such as mining on sloppy hills, bush burning and continuous cultivation are prevalent in the area [17]. Food insecurity, decline in agricultural productivity, loss of soil structure and soil fertility depletion are some of the severe ecological damages resulting from the massive soil loss in southeastern Nigeria [13 - 19]. The gully erosion incidences observed in the area have eroded about 45 to $90 \%$ of total sediment output on agricultural lands in the region [20].

The menace of soil erosion in this region has made agricultural practices in the area more challenging. Although, the traditional approach of soil sampling and laboratory analysis had been used to produce soil maps that have assisted and supported agro-based and scientific projects. However, the methodology has been consideredtime consumingand relatively expensive [21 23].Thus,remote sensing and GIS applications are appropriate methods for obtaining information about the spatial characteristics of the soils. Quick quantitative, high resolution and more accurate soil maps from remote sensing and GIS applications seem to have inundated the traditional soil maps [23]. This paper therefore presents a remote sensing and GIS based assessment of some soil parameters including soil texture, $\mathrm{pH}$ and drainage pattern.

\section{Study Area}

Southeast Nigeria consists majorly of Abia, Anambra, Enugu, Imo and Ebonyi States as shown in Figure 1. The area is characterized by a tropical climate with distinct wet and dry seasons and mean annual rainfall of about $1700 \mathrm{~mm}$ [24].Mangroove swamp is the vegetation commonly found in the coastal area to the rainforest and savanna is peculiar in the interior Abia and Abakaliki [25]. 


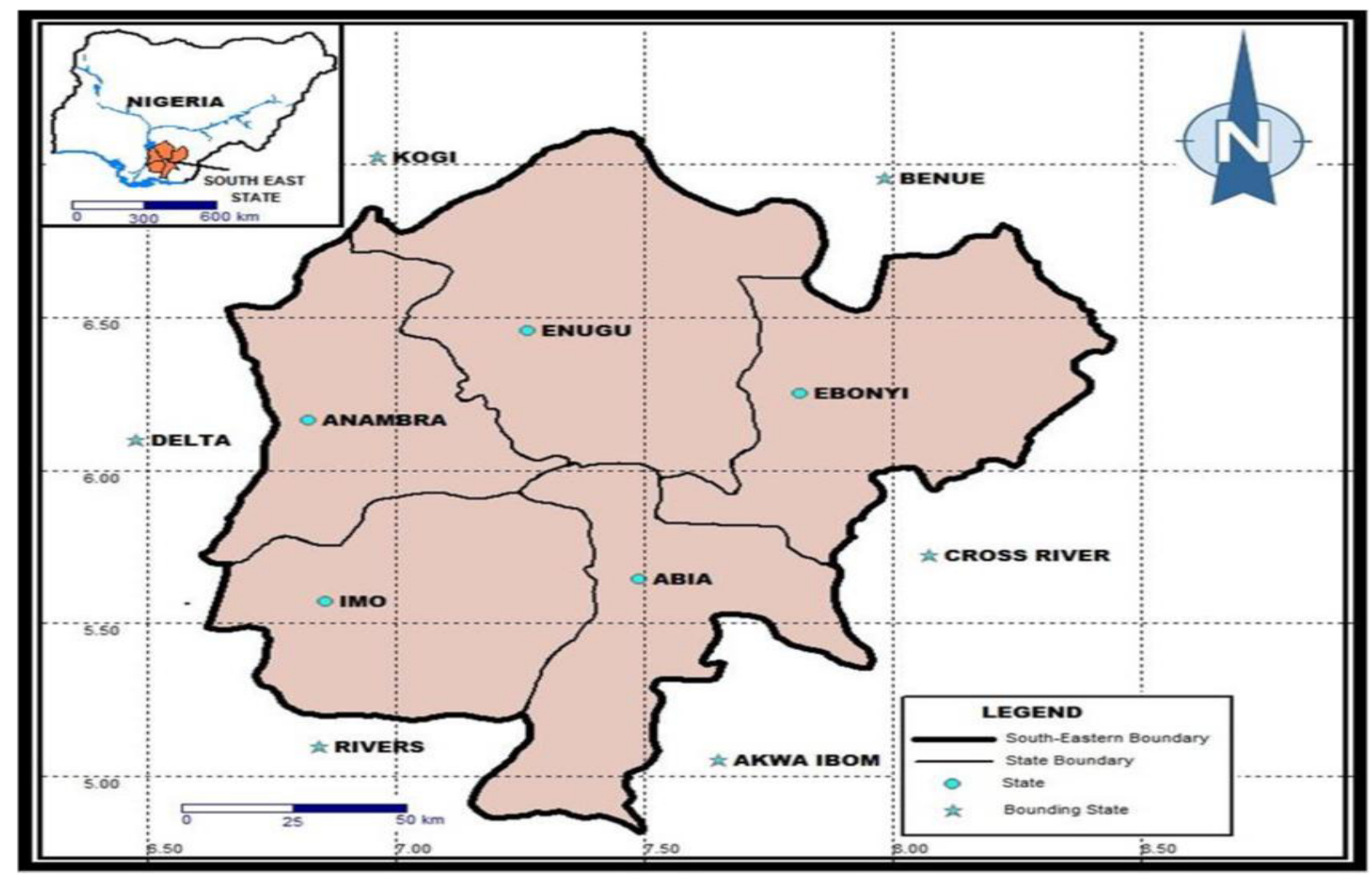

Figure 1: Map of Southeast Nigeria [13].

\section{Methodology}

Existing soil maps of Nigeria of sheets 1 to 8 at a displayable scale of 1: 650,000, acquired by the Federal Department of Agricultural Land Resources (FDALR,), Abuja, Nigeria and four sheets of the political map of Nigeria acquired from the office of the Surveyor General of the Federation, Abuja, Nigeria were used for this study [23]. The data were first studied to identify their weaknesses then scanned and spatially referenced to WGS (1984) UTM geographic coordinate system. GIS operation was carried ouLeica Geosystem ERDAS IMAGINE 9.1 and ESRI ArcGIS 9.3 were both use to carry out GIS operation. A non-spatial soil data base consisting soil $\mathrm{pH}$, texture and drainage patterns for the study area was created from the GIS interface after being checked and vectorized.

\section{Results and Discussion}

The results of the soil parameters investigated are discussed below.

\subsection{Soil $\mathrm{pH}$}

The measure of acidity and alkalinity in soils is known as soil $\mathrm{pH}$. This measurement of soil $\mathrm{Ph}$ is important as it determines how easily plants can absorb nutrients from the soil. Soil with a pH of 7 is considered neutral. The lower a soil's $\mathrm{pH}$ the more acidic it is, and the higher the $\mathrm{pH}$, the more alkaline the soil. Figure 2 presents the soil $\mathrm{pH}$ distribution for the study area. Anambra, part of Enugu and Ebonyi state have moderately acidic soils with soil $\mathrm{pH}$ ranging from 4.1 to 5.1. 
Moderately acidic to strongly acidic soils with soil $\mathrm{pH}$ range of 2.1 to 4.5 is dominant in Imo and some part of Anambra States. Towards the northern Ebonyi State and northern Enugu states has soils $\mathrm{pH}$ units ranging from slightly acidic to neutral. Enugu soils predominantly ranged from slightly acidic to slightly alkaline with soil ph range of 6.1 to 6.8 and 7.2 to 8.0. Imo and Abia States soils have soil pH units ranging from 2.0 to 3.0 and 6.2 to 6.8 that is, strongly acidic to slightly acidic while towards the eastern part of Enugu state soils $\mathrm{pH}$ units ranges from very strongly acidic to strongly alkaline.

For the study area the soil $\mathrm{pH}$ units with high dominance are the slightly acidic soils found in Ebonyi State and the strongly acidic soils found in Imo and Abia States. Crops take up nutrients from the soil when the nutrients are dissolved in water. Nutrients such as iron, nitrogen, phosphorus and potassium are not able to dissolve efficiently in soil solution when soil's $\mathrm{pH}$ is too acidic or too alkaline. Although factors such as temperature, previously grown crop or vegetation and rainfall can affect soil $\mathrm{pH}$ level. Dry climates will have more alkaline soils while areas with heavier rainfall will have more acidic soils.Nonetheless, farmers and horticulturists can adjust soil $\mathrm{pH}$ to suit their specific needs.

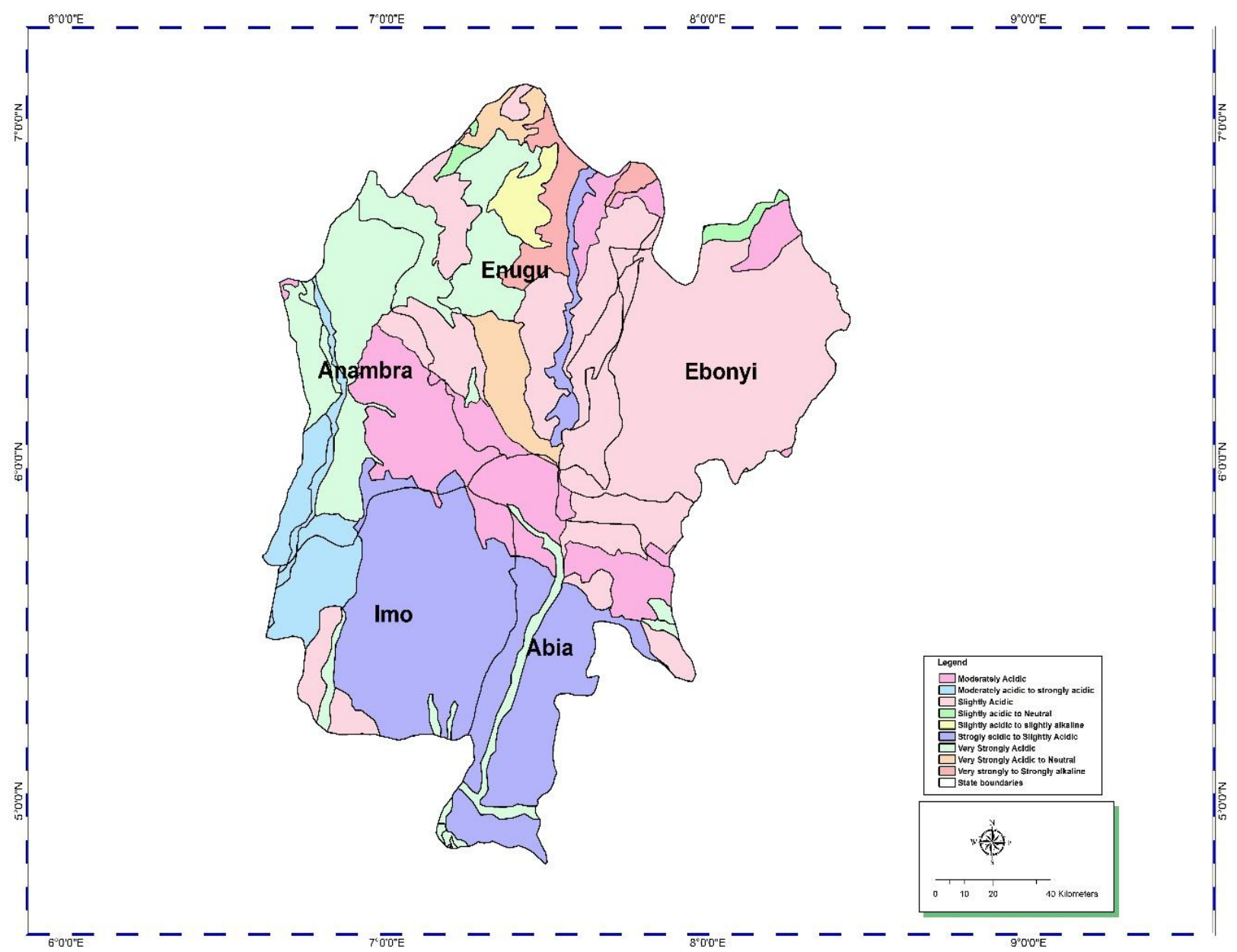

Figure 2: Soil pH distribution for Southeast Nigeria. 
3rd International Conference on Science and Sustainable Development (ICSSD 2019)

IOP Publishing IOP Conf. Series: Journal of Physics: Conf. Series 1299 (2019) 012070 doi:10.1088/1742-6596/1299/1/012070

\subsection{Soil Texture}

Soil texture is the relative weight percentage of sand, silt and clay of the soil. The texture of a soil determines soil characteristics that affect the growth of plants. Sand is the largest of the mineral particles. Sandy soils have large pore spaces that improves aeration and water flow through the pores easily. Although sandy soils lack the ability to hold nutrients and are not fertile, this group of soils are generally well drained. Figure 3 presents the soil texture distribution of the study area. Sandy clay texture are dominant in Anambra, Ebonyi and eastern Enugu.Sandy loam are observed to dominate Abia, Imo and most parts of Enugu. Silty clay is found towards the eastern flank of Enugu state while loamy fine sand is observed to have cut across central part of Enugu. Some portion of Anambra and Imo states are observed to have silty loamy soil texture in low proportion. While concretionary clay texture is noticeable towards the northeast of Enugu state.

Generally, southeast Nigeria has soil texture mostly composed of sandy clay and sandy loam soil. Although, Enugu state is noticed to have almost all the available soil texture found within the state. Clay is the smallest size of the soil particles and has the ability to hold nutrients and water that can be used by plants. They are relatively fertile soils but lack the capacity to adsorb cations, however, they contribute less to soil fertility. Clay has poor aeration and poor water drainage capacity due to small pore spaces. Sandy loamy soils are made up of sand particles with varying amount of silt and clay. This type of soil material is good for agriculture because it normally allows for good drainage but cannot hold sufficient water or nutrients for healthy plant growth. Sandy loam soil are often deficient in some micro nutrients frequent irrigation and fertilizer will be required to enhance it.

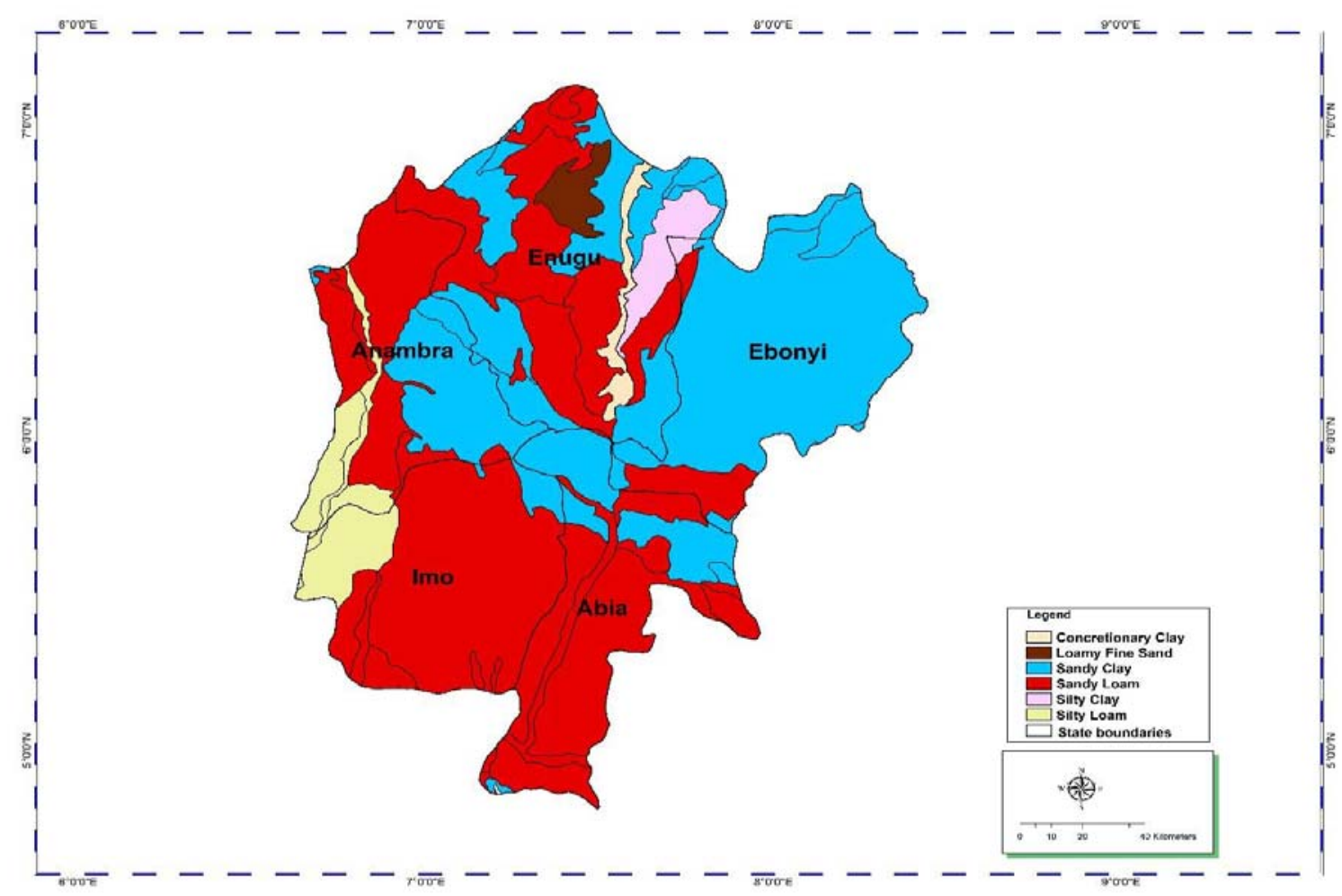

Figure 3: Soil texture map of southeast Nigeria 


\subsection{Soil Drainage Pattern}

Soil drainage is the natural removal of excess water from soil root zone as a result of the force of gravity. The water that supports springs, baseflow and aquifer recharge are provided by this natural process. Soil drainage improves soil moisture and ventilation, accelerates the drying of soils to maintain healthy plant root and also supports microbial activities. Figure 4 shows the soil drainage pattern distribution for the study area. Predominantly, Enugu, Ebonyi, Imo and Abia states have well drained soil pattern with pockets of poorly drained soil pattern towards northern Ebonyi and Enugu States; however, there is a small portion of imperfectly drained soil pattern towards the northeast portion of Enugu State. Soils of Anambra state are basically moderately drained but poorly drained towards the eastern part.

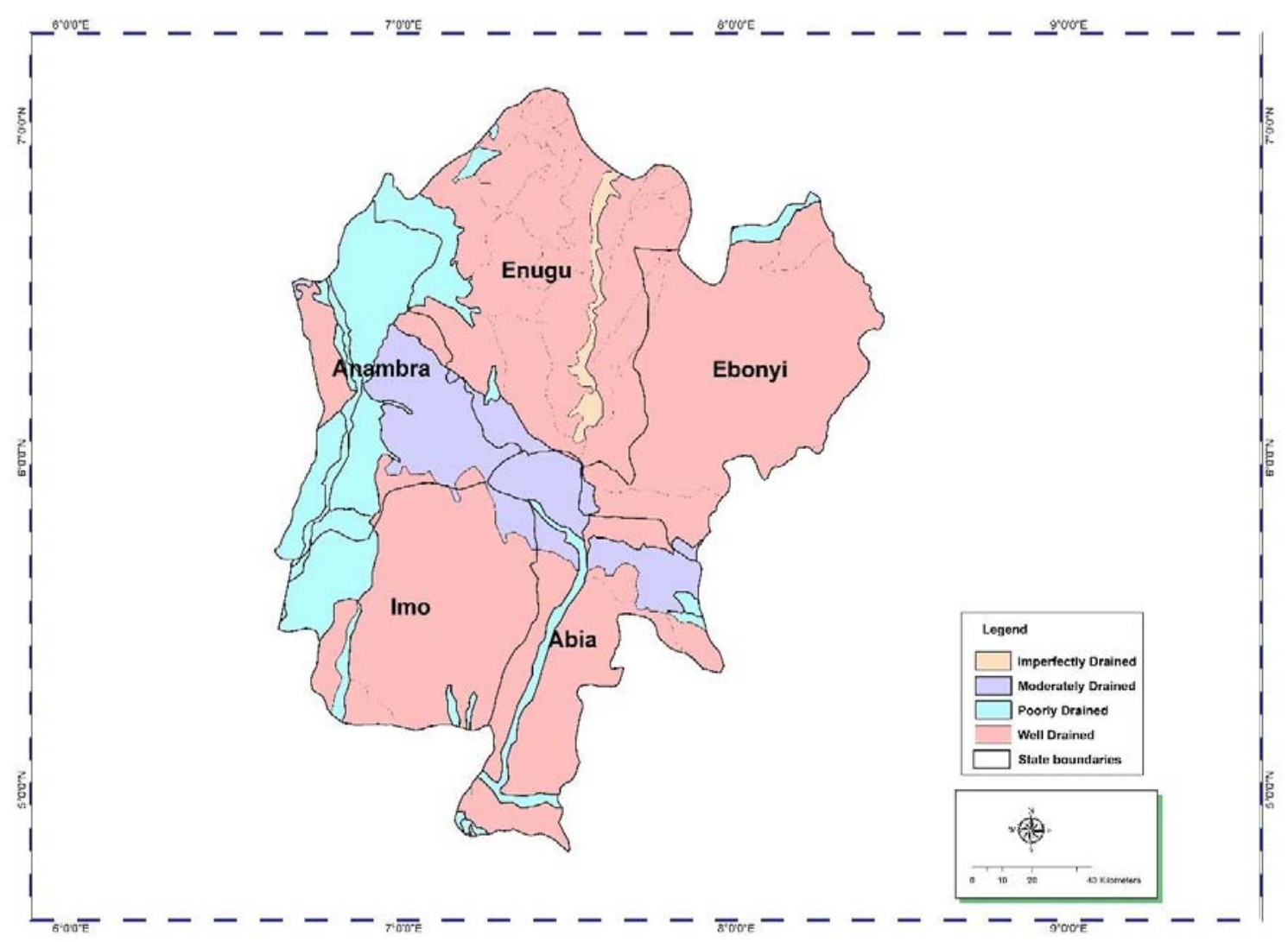

Figure 4: Soil drainage pattern for southeast Nigeria.

\section{Conclusion}

Remote sensing data and geographic information system have been used to map the spatial distribution of soil properties in southeast Nigeria. Soil parameters study can be used for soil amendment analysis, risk assessment and decision making necessary for precision farming. Crop yield is guaranteed on well drained soils and sandy loam soils of Imo, Abia and some portion of 
Anambra and Enugu States. Erosion is noted as one of the major causes of soil depletion in eastern Nigeria; thus, adequate soil management, frequent irrigation and fertilization may be required for utmost crops yield in the area. High resolution remote sensing techniques are highly recommended for soil mapping and monitoring because it allows for coverage of very large areas within the shortest time possible.

\section{Acknowledgement}

The authors wish to appreciate Nkwunonwo U.C of University of Portsmouth for his assistance andCovenant University Centre for Research, Innovation and Discovery for sponsoring this paper.

\section{References}

[1] Aminuddin, B. Y, Zulkefli, I, Abd Razak, H, Abdul Munir, J., Abdul Rahim, A (2003). Mapping soil and nutrient variations for precision fertilizer management in rice farm. Paper presented at the conference modern rice farming, 13 - 16 Oct. 2003, AlorSetar. Organisers: MARDI, MAPPS, MADA and IRRI.

[2] Akanji, A. M, Oshunsanya, O. S, Alomran, A. (2018). Electrical conductivity method for predicting yields of two yam (Dioscoreaalata) cultivars in a coarse textured soil, International Soil and Water Conservation Research6 (3): 230 - 236.

[3] Kayode, O. T and Akinwumi, I. I. (2017). Residual soils derived from charnockite and migmatite as road pavement, Journal of Material and Environmental Sciences 8 (2): $657-665$.

[4] Emetere, M. E, Omotosho, T. V and Kayode, O (2016). On the determination of agricultural prospects using remote sensing and field techniques, Aip Conference

Proceedings 1707 (1).

[5] Aizebeokhai, A. P, Oyeyemi, K. D and Kayode, O. T (2016). Assessment of soil petrophysical parameters using electrical resistivity tomography (ERT) and induced polarization techniques, Research Journal of Applied Sciences 10 (9): 479 - 485.

[6] Filella, M, Williams, A. P and Belzile, N (2009). Antimony in the environment: Knowns and unknowns. Environmental Chemistry 6 (2): 95 - 105.

[7] Martin, K. L, Girma, K, Freeman K. W, Teal R. K, Tubaña B, and Arnall D. B (2007).

Expression of variability in corn as influenced by growth stage using optical sensor measurements.Agronomy Journal,99: 384 - 389.

[8] Guo, M. J and Trotter, M. C (2006). Estimating photosynthetic light-use efficiency using the photochemical reflectance index: The effects of short-term exposure to elevated $\mathrm{CO} 2$ and low temperature, International Journal of Remote Sensing 27 (20): 4677 - 4684.

[9] Kerr, J. T and Ostrovsky, M. (2003). From Space to Species: Ecological Applications for Remote Sensing. Trends in Ecology and Evolution, 18, 299 - 305.

[10] Running, S. W, Baldocchi D. D, Turner D. P, Gower S. T, Bakwin P. S and Hibbard K. A (1999). A global terrestrial monitoring network integrating tower fluxes, flask sampling, $108-127$. ecosystem modeling and EOS satellite data. Remote Sensing of Environment, 70,

[11] Mehrez, Z, Nicolas, B, and Michel, N, "Remote Sensing of Soil," Applied and 
Environmental Soil Science, vol. 2011, Article ID 904561, 2 pages, 2011 . https://doi.org/10.1155/2011/904561

[12] Ume, N. C, Enwereuzor, A. I, Egbe, C. A, Ike, M. C and Umo, S.J (2014). Application of Geographic information system and remote sensing in identifying the impacts of gully erosion in Urualla, Ideato North, Local Government area, Imo state. Nigeria Global Research Journal of Science 3 (3):1 - 8.

[13] Onoja, S. U, Nweze, E1, Mattias, A, Ejere,V. C (2015). Evaluation of bacteriological quality and essential elements in commercially bottled/packaged water produced and marketed in Southeastern Nigeria. African Journal of Microbiology Research 9 (28): 1728 - 1737.

[14] Adekalu, K. O, Olorunfemi, I. A, and Osunbitan, J. A (2007). Grass mulching effect on infiltration, surface runoff and soil loss of three agricultural soils in Nigeria,

Bioresource Technology, 98(4): 912-917.

[15] Idowu, O. J and Oluwatosin, G. A (2008), Hydraulic Properties in relation to morphology of a tropical soil with hardened plinthite under time land use types, Tropical and Subtropical Agro Ecosystems 8 (4): 145 - 155.

[16] Okpala, A. O (1990). Nigerian population growth and its implications for economic development, Scandinavian Journal of Development Alternatives, 9 (4): 63-77.

[17] Nwachukwu, O. I and Onwuka, M. I (2011). Land Degradation and Food crisis-causes, impact and soil conservation efforts in Nigeria: Globalization and rural development in Nigeria. Ike Nwachukwu and Ken C.Ekwe (eds). Michael Okpara University of Agriculture Umudike, Nigeria 231-232 pp.

[18] Junge, B, Abaidoo, R, Chickoye, D, Stahr, K, and Lal, R (2008). Research Report on Soil Conservation in Nigeria: Past and present on - station and on farm initiatives. Soil and water conservation society, Ankeny, Iowa, USA, 12 - 16.

[19] Eswaram, H, Lal, R, and Reich, P. F (2001). Land degradation: an overview.In Response to Land Degradation, eds. E. M. Bridges, I. D pp.132- 143.

[20] Ogbonna J. U and Ijioma M. A (2010). Mapping gully erosion susceptibility in old Imo State, Nigeria using probability and statistics model, American Journal of Geographic Information Systems 3 (3): $45-50$.

[21] Aizebeokhai, A. P, Okenwa, N. U, Oyeyemi, K. D, Kayode, O. T and Adeyemi, G. A (2018). Soil characterization using remote sensing in southwestern Nigeria: Implications for precision agriculture, Earth and Environmental Science 173; 1 - 6.

[22] Lark, M (2007), Background to Digital Soil Mapping. International Working group on Digital Soil Mapping Commission 1.5 Pedometrics. Rothamsted Research, Harpenden Hertfordshire, United Kingdom.

[23] Nkwunonwo, U. C and Okeke, F. I (2013). GIS-based production of digital soil map for Nigeria Ethiopian Journal of Environmental Studies and Management (6) 5: 499 - 506.

[24] Ahamefule, H.E and Mbagwu, J. S. C (2007). Effects of phosphorus and four tillage mulch systems on the physico-chemical properties of an ultisol in Eastern Nigeria, AgroScience, 6 (1): 25 - 32.

[25] Chukwu, G. O, Ezenwa, M. I. S, Osunde, A. O, Asiedu, R (2007). Spatial distribution of $\mathrm{N}, \mathrm{P}$ and $\mathrm{K}$ in major yam soils of southeastern Nigeria, African Journal of Biotechnology 6 (24): 2803 - 2806. 